\title{
Low pH immobilizes and kills human leukocytes and prevents transmission of cell-associated HIV in a mouse model Stuart S Olmsted ${ }^{1,2}$, Kristen V Khanna ${ }^{3}$, Erina M Ng1, Steven T Whitten ${ }^{1}$, Owen N Johnson III ${ }^{1}$, Richard B Markham ${ }^{4}$, Richard A Cone*1,3 and Thomas R Moench ${ }^{3}$
}

Address: ${ }^{1}$ Department of Biophysics, Johns Hopkins University, Jenkins Hall, 3400 N. Charles St., Baltimore, MD 21218, USA, ${ }^{2 R A N D}$ Corporation, 201 N. Craig St \#202, Pittsburgh, PA 15213, USA, ${ }^{3}$ ReProtect, Inc., 703 Stags Head Rd, Baltimore, MD 21286, USA and ${ }^{4}$ Department of Molecular Microbiology and Immunology, Johns Hopkins Bloomberg School of Public Health, 615 North Wolfe Street, Suite E5132, Baltimore, MD 21205 USA

Email: Stuart S Olmsted - olmsted@rand.org; Kristen V Khanna - kkhanna@reprotect.com; Erina M Ng - erina.ng@jhu.edu; Steven T Whitten - swhitten@redstormscientific.com; Owen N Johnson - zeropr96@earthlink.net; Richard B Markham - rmarkham@jhsph.edu; Richard A Cone* - cone@jhu.edu; Thomas R Moench - tmoench@reprotect.com

* Corresponding author

Published: 30 September 2005

BMC Infectious Diseases 2005, 5:79 doi:10.1 I86/147/-2334-5-79
Received: 18 May 2005

Accepted: 30 September 2005

This article is available from: http://www.biomedcentral.com/I47I-2334/5/79

(C) 2005 Olmsted et al; licensee BioMed Central Ltd.

This is an Open Access article distributed under the terms of the Creative Commons Attribution License (http://creativecommons.org/licenses/by/2.0), which permits unrestricted use, distribution, and reproduction in any medium, provided the original work is properly cited.

\begin{abstract}
Background: Both cell-associated and cell-free HIV virions are present in semen and cervical secretions of HIVinfected individuals. Thus, topical microbicides may need to inactivate both cell-associated and cell-free HIV to prevent sexual transmission of HIVIAIDS. To determine if the mild acidity of the healthy vagina and acid buffering microbicides would prevent transmission by HIV-infected leukocytes, we measured the effect of $\mathrm{pH}$ on leukocyte motility, viability and intracellular $\mathrm{pH}$ and tested the ability of an acidic buffering microbicide (BufferGel ${ }^{\circledR}$ ) to prevent the transmission of cell-associated HIV in a HuPBL-SCID mouse model.
\end{abstract}

Methods: Human lymphocyte, monocyte, and macrophage motilities were measured as a function of time and $\mathrm{pH}$ using various acidifying agents. Lymphocyte and macrophage motilities were measured using video microscopy. Monocyte motility was measured using video microscopy and chemotactic chambers. Peripheral blood mononuclear cell (PBMC) viability and intracellular $\mathrm{pH}$ were determined as a function of time and $\mathrm{pH}$ using fluorescent dyes. HuPBL-SCID mice were pretreated with BufferGel, saline, or a control gel and challenged with HIV-I-infected human PBMCs.

Results: Progressive motility was completely abolished in all cell types between $\mathrm{pH} 5.5$ and 6.0. Concomitantly, at and below $\mathrm{pH} 5.5$, the intracellular $\mathrm{pH}$ of PBMCs dropped precipitously to match the extracellular medium and did not recover. After acidification with hydrochloric acid to $\mathrm{pH} 4.5$ for $60 \mathrm{~min}$, although completely immotile, $58 \%$ of PBMCs excluded ethidium homodimer-I (dead-cell dye). In contrast, when acidified to this $\mathrm{pH}$ with BufferGel, a microbicide designed to maintain vaginal acidity in the presence of semen, only $4 \%$ excluded dye at $10 \mathrm{~min}$ and none excluded dye after $30 \mathrm{~min}$. BufferGel significantly reduced transmission of HIV-I in HuPBL-SCID mice (I of 12 infected) compared to saline ( 12 of 12 infected) and a control gel ( 5 of 7 infected).

Conclusion: These results suggest that physiologic or microbicide-induced acid immobilization and killing of infected white blood cells may be effective in preventing sexual transmission of cell-associated HIV. 


\section{Background}

Most HIV transmission occurs sexually [1,2], and semen [3-6] and cervicovaginal secretions [7] contain free HIV virions as well as HIV-infected leukocytes. Whether cellfree virus or infected cells are the primary means of transmission, or whether both are important remains unknown.

Free virus transmits infection in monkey [8], chimpanzee [9], and cat [10] vaginal-challenge models, although the amount of virus used [8] has generally been greater than the amount of infectious virus found in semen of HIVinfected men [4]. Studies of cell-vectored transmission include an unsuccessful attempt to establish a model of vaginal transmission with cryopreserved SIV-infected cells in the monkey [8], but, fresh HIV-infected cells transmitted infection in the chimpanzee when applied to the cervical os [9], fresh FIV-infected cells transmitted infection after vaginal deposition in the cat $[10,11]$, and fresh HIVinfected human peripheral blood leukocytes transmitted infection to SCID mice after vaginal deposition $[12,13]$. Notably, foreign lymphocytes are able to migrate through vaginal mucosa and reach the iliac lymph nodes of mice $[14,15]$ and HIV-1 infected mononuclear cells are capable of transmigrating through a monolayer of human epithelial cells [16].

Topical microbicides are being developed to reduce the sexual transmission of HIV and other STDs. The presence of both free HIV virions and HIV-infected cells in sexual secretions, and the demonstrated ability of both to transmit infection in diverse animal models, suggests that microbicide candidates should protect against cell-associated HIV as well as cell-free HIV.

Foremost, vaginal microbicides should not injure or disrupt the normal vaginal flora or the vaginal epithelium; thus, microbicides designed to enhance and maintain natural vaginal protective mechanisms merit careful consideration. One natural protective mechanism is the mild acidity found in the healthy vagina $(\sim \mathrm{pH} 4)$ that is generated predominately by the lactic acid produced by vaginal lactobacilli $[17,18]$ and is thought to inhibit harmful flora and some STD pathogens. Two microbicides (Buffer$\mathrm{Gel}^{\circledast}$ (ReProtect, Inc., Baltimore, MD) [19-21] and Acidform (TOPCAD, Chicago, IL) [22]), have been developed with the goal of strengthening and maintaining vaginal acidity, by having sufficient buffer capacity to block the alkalinizing action of semen. Another microbicide, CAP, also has acidic buffering properties, which have been postulated to contribute to its activity [23-25]. BufferGel is being tested in an HIV prevention efficacy trial (HPTN 035), and a commercially-available acidifying lubricating gel (Replens ${ }^{\circledR}$ ) is being used together with a cervical barrier (diaphragm) in an HIV prevention trial [26].
In these studies, we examined the ability of mild acidity to inhibit lymphocyte, monocyte and macrophage motility. We also determined PBMC viability in mildly acidic conditions, and measured the intracellular $\mathrm{pH}\left(\mathrm{pH}_{\mathrm{i}}\right)$ to determine their ability to defend their cytoplasmic $\mathrm{pH}$. We report the effect of Carbopol $^{\circledR}$, the buffering agent contained in BufferGel, on leukocyte motility and PBMC viability. Finally, we tested the ability of BufferGel to reduce transmission of cell-associated HIV in the HuPBL-SCID mouse model.

\section{Methods \\ PBMC collection}

Venous blood and semen were obtained from donors according to procedures approved by the Review Board on the Use of Human Subjects at the Johns Hopkins University. PBMCs were separated on Histopaque ${ }^{\circledR} 1077$ step gradients (Sigma, St Louis, MO). Cells were maintained at $37^{\circ} \mathrm{C}$ during experiments and were used within 5 hours of collection.

\section{Monocyte chemotaxis}

Gradient purified PBMCs were washed twice in $0.9 \%$ saline and resuspended in $0.9 \%$ saline at a concentration of $10^{8}$ cells $/ \mathrm{ml}$. Monocyte chemotactic experiments were performed using microchambers with polycarbonate filters with $5 \mu \mathrm{m}$ pores (NeuroProbe, Cabin John, MD). The top wells of the microchamber were filled with neutral or acidified RPMI (Gibco, Rockville, MD) supplemented with $1 \%$ fetal bovine serum (FBS, Gibco) and then the cell suspension was added. RPMI was acidified with one or combinations of the following acids: acetic acid (JT-Baker, Phillipsburg, NJ), $\mathrm{HCl}$ (JT-Baker), or 2-(N-Morpholino)ethanesulfonic acid (MES, Sigma). The bottom wells were filled with RPMI supplemented with 1\% FBS at the same $\mathrm{pH}$ and a chemoattractant; either $0.1 \mu \mathrm{M}$ formylMet-Leu-Phe (FMLP, Sigma) or $5 \mu \mathrm{M}$ platelet activating factor (PAF, Sigma). The chamber assembly was then incubated for 90 minutes at $37^{\circ} \mathrm{C}, 5 \% \mathrm{CO}_{2}$. After incubation, $\mathrm{pH}$ in upper and lower chambers was verified to have remained stable $( \pm 0.1 \mathrm{pH}$ units, MI-414-6 $\mathrm{pH}$ microelectrode, Microelectrodes Inc., Bedford, NH), the chambers were disassembled, stained with Diff-Quick ${ }^{\circledast}$ (American Scientific Products, McGaw Park, IL) and the number of monocytes that had migrated to the lower side of the filter counted.

\section{Monocyte, macrophage and lymphocyte chemokinesis}

PBMCs separated and washed as above were resuspended in $15 \mathrm{ml}$ RPMI containing either 1\% FBS for monocyte or lymphocyte purification or 10\% human serum (HS) for macrophage maturation. Monocytes were separated from lymphocytes by reversible fibronectin adherence [27] resulting in $90 \%$ monocyte purity as judged by morphology after Diff-Quick staining. For experiments requiring 
macrophages, the monocytes were additionally incubated for 3 days in RPMI containing 10\% HS [28], and matured macrophages were harvested. For lymphocyte experiments, monocytes were depleted from PBMCs with CD14-coated magnetic beads (Dynal Biotech, Lake Success, NY) according to the manufacturer's protocol. The remaining cells were predominantly lymphocytes (less than 2\% monocytes by Diff-Quick staining).

Leukocytes were observed by video microscopy for movement on glass microscope slides (VWR, Bridgeport, NJ) using a published method [29] modified as described below. Monocytes and macrophages were pelleted in a microcentrifuge at $400 \mathrm{G}$ and resuspended in RPMI containing 0.125\% Carbopol (BF Goodrich, Cleveland, OH), serum and chemoattractant (1\% FBS and $0.1 \mu \mathrm{M}$ FMLP for monocytes and 10\% HS and $0.1 \mathrm{nM}$ FMLP for macrophages). Lymphocytes were resuspended in RPMI containing 1\% FBS, $0.1 \mu \mathrm{M}$ FMLP, and either $50 \mathrm{mM}$ MES or $0.125 \%$ Carbopol. The media had previously been adjusted to the desired $\mathrm{pH}$, and the $\mathrm{pH}$ of the cell suspensions were verified immediately before placing them under coverslips for video microscopy. Video recordings were made for 15 minutes and then observed at high speed to assess the motility of each of the 50-200 cells contained in a low power field.

\section{PBMC viability}

PBMCs were washed in Hanks' Balanced Salt Solution without $\mathrm{Ca}^{+2}$ and $\mathrm{Mg}^{+2}$ (HBSS; Gibco BRL), resuspended in $10 \mathrm{ml}$ RPMI, and $4 \times 10^{6}$ cells were placed in microcentrifuge tubes. Tubes were spun at $400 \mathrm{G}$ for 7 minutes and all supernatant removed using drawn out capillary tips, and cells were resuspended in seminal plasma obtained by centrifugation of fresh semen.

PBMCs in seminal plasma $(0.05,0.1$, or $0.2 \mathrm{ml})$ were added to glass vials containing $0.1 \mathrm{~g}$ of BufferGel and stirred. Vials were maintained at $37^{\circ} \mathrm{C}$ during incubations. Additionally, PBMCs were resuspended in seminal plasma with or without $0.2 \%$ Carbopol. These samples were observed at $\mathrm{pH} 7.4$ or acidified with $\mathrm{HCl}$ to $\mathrm{pH} 4.5$. Each cell suspension was monitored and $\mathrm{pH}$ adjusted throughout the timed incubations (1-60 minutes) with the $\mathrm{pH}$ microelectrode, and adjusted with $0.1 \mathrm{~N} \mathrm{NaOH}$ or $\mathrm{HCl}$ as necessary to maintain the $\mathrm{pH}$ to within $0.03 \mathrm{pH}$ units of the starting $\mathrm{pH}$. After timed incubations, samples were neutralized with $2 \mathrm{ml}$ RPMI with $25 \mathrm{mM}$ HEPES (pH 8.5) (Gibco BRL) and $\mathrm{NaOH}$ (JT-Baker) was used as needed to bring pH to 7.0-7.4. Neutralized cell suspensions were incubated with $2 \mu \mathrm{M}$ calcein AM and $12 \mu \mathrm{M}$ ethidium homodimer (Molecular Probes, Eugene, OR) and observed with an epifluorescent Nikon E-800 microscope and live and dead cells counted.

\section{PBMC intracellular $\mathbf{p H}$}

PBMCs were labeled with $50 \mu \mathrm{M}$ Oregon Green ${ }^{\mathrm{TM}} 488$ carboxylic acid diacetate or $50 \mu \mathrm{M}$ carboxyfluorescein diacetate (Molecular Probes) for 35 minutes. Fluorescently labeled platelets were removed by four $120 \mathrm{G}$ washes. PBMCs were resuspended at $5 \times 10^{5}$ cells $/ \mathrm{ml}$ in either HBSS or a high potassium medium containing $17.8 \mathrm{mM}$ $\mathrm{NaCl}, 125.2 \mathrm{mM} \mathrm{KCl}, 8.7 \mathrm{mM} \mathrm{Na}_{2} \mathrm{HPO}_{4}, 1 \mathrm{mM} \mathrm{Ca}_{2} \mathrm{Cl}, 1$ $\mathrm{mM} \mathrm{MgCl}_{2}$ (all JT-Baker), $1.5 \mathrm{mM} \mathrm{KH}_{2} \mathrm{PO}_{4}, 5 \mathrm{mM}$ D-glucose (both Sigma). Cell viability was determined with trypan blue (Sigma) exclusion. Standard curves were obtained using Nigericin (Molecular Probes), a $\mathrm{K}^{+} / \mathrm{H}^{+}$ ionophore to equalize the intracellular and extracellular $\mathrm{pH}$ of leukocytes in the high potassium medium [30-33]. Aliquots of labeled leukocytes were acidified and fluorescence ratio measurements were taken (ex: $490 \mathrm{~nm} / 440$ $\mathrm{nm}$, with em: $520 \mathrm{~nm}$ for Carboxyfluorescein and $555 \mathrm{~nm}$ for Oregon Green) as a function of time, and ratiometric measurements were made as a function of time on an LS50B fluorometer (Perkin Elmer, Norwalk, CT).

Intracellular $\mathrm{pH}$ measurements were also performed using microscopic fluorescent ratiometry using the same dyes and wavelengths as in the cuvette experiments. Aliquots of PBMCs were placed onto Labtek chambered slides (Nalgene-Nunc International, Rochester, NY) coated with $0.1 \%$ polylysine (Sigma), labeled and washed. Individual cells were imaged and fluorescence measured in standard and high potassium/ionophore buffer using an Axiovert light microscope (Zeiss, Thornwood, NY) and IP Lab software (Scanalytics, Fairfax, VA).

\section{HuPBL-SCID mouse model}

The HuPBL-SCID mouse was used to model vaginal transmission of HIV-1 as previously described [13,34]. Briefly, SCID mice were administered uninfected human, peripheral blood mononuclear cells (HuPBMC) to the peritoneal cavity one week prior to inoculation, and treated with $2.5 \mathrm{mg}$ Depo-Provera (Upjohn Pharmaceutical, Kalamazoo, MI), which thinned the vaginal epithelium. Vaginal inoculation of $10^{6} \mathrm{HIV}$-1-infected HuPBMC followed vaginal administration of $10 \mu \mathrm{L}$ of PBS, KY jelly, or BufferGel. The inoculated HIV-infected cells, of which between 1 and $5 \%$ of the cells are infected with HIV-1 as demonstrated by limiting dilution PCR, were administered on day 10 postinfection. On day 14 following vaginal inoculation, the mice were euthanized and cells from the peritoneal cavity, of both human and murine origin, were collected. HIV-1infected cells within this population may originate from the infected-cell inoculum, or may be the human target cells from the peritoneal transplant within which the virus has replicated. These cells were placed into culture with PHA-stimulated T cells for co-culture of HIV-1, and were detected by HIV-1 p24 antigen ELISA. 

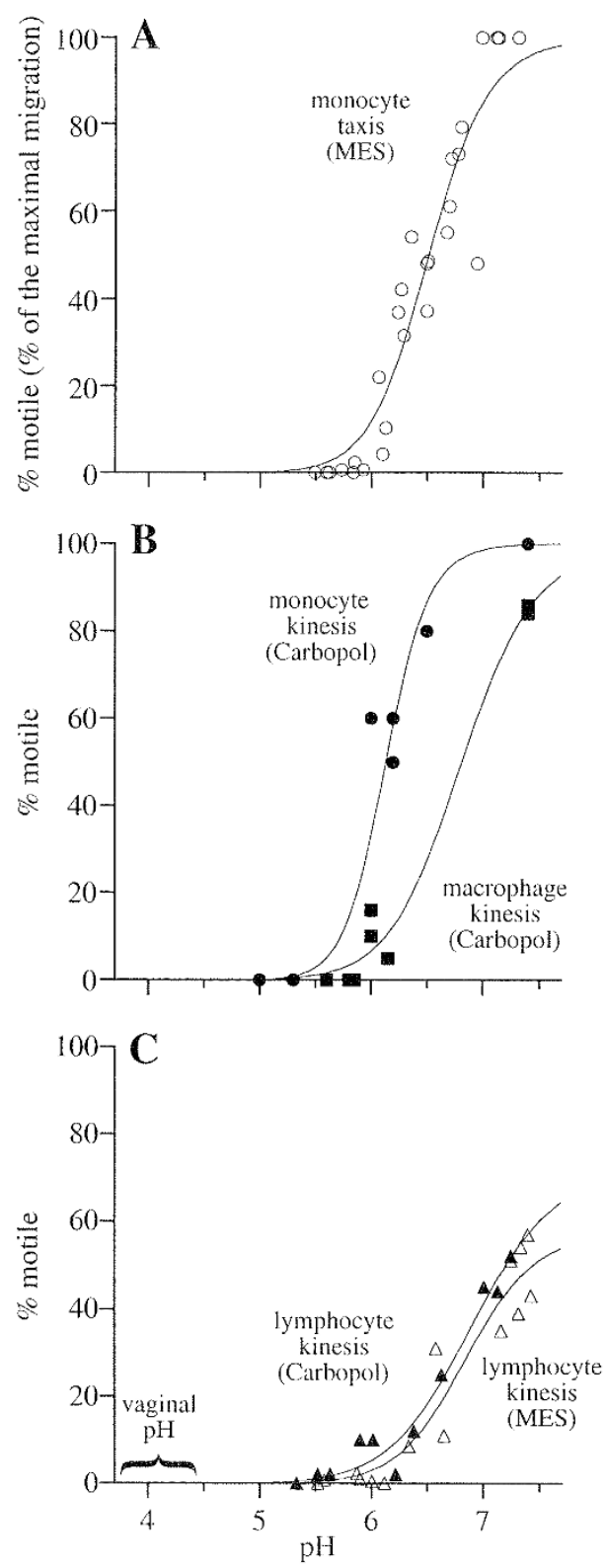

\section{Figure I}

Leukocyte chemotactic and chemokinetic response as a function of $\mathrm{pH}$. A. Monocyte chemotactic response, as measured by monocytes migrating through filters of nucleopore chambers, is plotted as a function of $\mathrm{pH}$. Monocyte chemotactic response is normalized to the maximal response for each of four repeats of the experiment (maximum response was between $\mathrm{pH} 7.0$ and 7.3 for each repeat). The cells were in RPMI containing $50 \mathrm{mM}$ MES. Similar results were observed when the media were acidified with buffering systems consisting of $20 \mathrm{mM}$ acetic acid, $20 \mathrm{mM}$ MES and $20 \mathrm{mM}$ acetic acid, and I N $\mathrm{HCl}$ and when PAF was used as an alternative chemoattractant (data not shown). B. Monocyte (circles) and macrophage (squares) chemokinesis, as measured by observing cells migrating on glass slides, is plotted as a function of $\mathrm{pH}$. The percent response was determined by the number of motile cells divided by the total number of cells (50-200) observed at each $\mathrm{pH}$. The cells were in RPMI containing $0.125 \%$ Carbopol. C. Lymphocyte (triangles) chemokinesis is plotted as a function of $\mathrm{pH}$. The percent response was determined as in B. The cells were in RPMI containing 50 mM MES (open triangles) or RPMI containing $0.125 \%$ Carbopol (closed triangles). Nonlinear regression was used to fit a sigmoidal curves for each data set: $\mathbf{A}: \mathbf{R}=$ 0.95; B: $R=0.95$, monocytes, 0.99 macrophages; $\mathbf{C}: R=.98$ lymphocytes with Carbopol, $R=.96$ with MES. The minimum value was set to 0 for all curves and the maximum value to 100 for monocyte and macrophage curves. The bracket from $\mathrm{pH}$ 3.7 to 4.4 on the $x$ axis of panel $\mathrm{C}$ indicates the $\mathrm{pH}$ range in a healthy, lactobacilli dominated vagina. 


\section{Statistics}

Results from leukocyte chemotaxis and chemokinesis experiments were fit with sigmoidal curves by nonlinear regression. Curves were fit to the four parameter logistics equation [35]:

$y=\left((d-a) /\left(1+(x / c)^{b}\right)\right)+a$

where $\mathrm{a}$ is the maximum asymptote, $\mathrm{b}$ is the slope of the linear region of the curve, $\mathrm{c}$ is the midpoint of the linear region, and $\mathrm{d}$ is the minimum asymptote. For monocytes and macrophages, the maximum asymptote was set to 100 and for all three cell types, the minimum asymptote was set to 0 , since values above 100 and below 0 are not physiological.

Statistical analyses were performed using SPSS ${ }^{\circledR}$ statistical software version 10.0 (SPSS Inc., Chicago, IL). Results from the PBMC viability experiments were analyzed by analysis of variance for the main effects of time and $\mathrm{pH}$ and for their interaction. Post hoc pair-wise group comparisons were made using Schéffe's multiple comparison procedure. A linear regression model was developed to determine whether there was a significant difference in viability between PBMCs acidified with $\mathrm{HCl}$ and BufferGel, after adjusting for the effects of time and the interaction between time and the acidifying agent. Results for the Hu-PBL SCID mouse model were analyzed with a two sided Fisher's exact test.

\section{Results}

Monocyte chemotactic response was observed using chemotactic chambers, over the $\mathrm{pH}$ range of $\mathrm{pH} 5.0$ to 7.5, in RPMI acidified and buffered with $50 \mathrm{mM}$ MES. Monocytes attracted by FMLP crawl through a filter separating two chambers filled with media. The percent response normalized to maximal response ( $\mathrm{pH} 7.0-7.5)$ is plotted for four experiments (Fig. 1A). Chemotaxis was essentially blocked below $\mathrm{pH}$ 5.8. Similar results were observed when the media were acidified with buffering systems consisting of $20 \mathrm{mM}$ acetic acid, $20 \mathrm{mM}$ MES and $20 \mathrm{mM}$ acetic acid, and $1 \mathrm{~N} \mathrm{HCl}$ without additional buffering agent and when PAF was used as the chemoattractant (data not shown).

Since Carbopol consists of micron-sized clusters of lightly cross-linked polymer, it clogged the filters of the microchamber assembly. Therefore, monocyte, macrophage, and lymphocyte chemokinesis were observed in RPMI containing FMLP and $0.125 \%$ Carbopol or $50 \mathrm{mM}$ MES by videotaping cells migrating on glass slides. In all cases, nearly all motility ceased below pH 5.8 (Fig. 1B and 1C). The chemokinesis results for monocytes, macrophages, and lymphocytes were similar to the results for monocyte chemotaxis through filters. Although monocytes and macrophages were occasionally able to change shape between $\mathrm{pH} 5$ and 6 , progressive motility was never observed below pH 6.0. Lymphocytes exhibited lower maximal motility rates at neutral $\mathrm{pH}(40-50 \%)$ than monocytes or macrophages (85-100\%).

To determine if the loss of cell motility was due to killing of the PBMCs, cell viability was tested using a fluorescent live/dead cell assay [36]. As shown in Fig. 2, PBMCs in seminal plasma acidified with $\mathrm{HCl}$ to $\mathrm{pH} 4.5$ maintained their viability substantially longer than PBMCs in seminal plasma acidified with BufferGel to $\mathrm{pH} 4.5(\mathrm{P}=0.001)$. When acidified with $\mathrm{HCl}, 80 \%$ of PBMCs were still viable at 30 minutes, but when acidified to this same $\mathrm{pH}$ with BufferGel, less than $10 \%$ were viable at 5 minutes and none were viable at 30 minutes. To test if this enhanced killing was due to Carbopol, or other constituents or the gel structure of BufferGel, PBMCs were resuspended in seminal plasma containing $0.2 \%$ Carbopol (approximately 20-fold lower concentration than in BufferGel) and adjusted to $\mathrm{pH} 4.5$ with $\mathrm{HCl}$, and the viability was measured. This is also relevant for situations where the concentration of Carbopol may be low due to uneven distribution of gel in the vagina. At 30 minutes, $50 \%$ of PBMCs in pH 4.5 RPMI containing 0.2\% Carbopol were viable. However, PBMCs incubated with $0.2 \%$ Carbopol at $\mathrm{pH} 7.4$ had no reduction in viability over one hour.

PBMC $\mathrm{pH}_{\mathrm{i}}$ was measured as a function of extracellular $\mathrm{pH}$ $\left(\mathrm{pH}_{\mathrm{e}}\right)$ to investigate potential mechanisms mediating the acid immobilization and killing of PBMCs. At every $\mathrm{pH}$ tested, $\mathrm{pH}_{\mathrm{i}}$ equilibrated with $\mathrm{pH}_{\mathrm{e}}$ within 2 minutes (Fig. 3). At $\mathrm{pH}_{\mathrm{e}}$ as low as 6.0, however, PBMCs were able to restore their $\mathrm{pH}_{\mathrm{i}}$ to approximately 7.5 within 10 minutes. However, at $\mathrm{pH} 5.5$ and below, PBMCs were unable to restore their normal $\mathrm{pH}_{\mathrm{i}}$, even after 60 minutes.

Control experiments using fluorescent microscopy were performed measuring the fluorescence ratio of individual cells and of the surrounding buffer, to detect artifacts due to possible dye leakage out of cells and inadvertent observation of dye in the extracellular buffer. These results showed that dye leakage was not a factor and that, as with the cuvette method, $\mathrm{pH}_{\mathrm{i}}$ dropped to $\mathrm{pH}_{\mathrm{e}}$ at both $\mathrm{pH}_{\mathrm{e}} 5.5$ and 5.0 and $\mathrm{pH}_{\mathrm{i}}$ did not recover (data not shown).

Three groups of mice were challenged with cell-associated HIV in the HuPBL-SCID mouse model. Depo-Provera treated mice were treated with BufferGel, PBS (control), or KY Jelly (gel control) prior to infected-cell challenge. One of 12 mice pretreated with BufferGel became infected with HIV, 12 of 12 mice pretreated with PBS became infected, and 5 of 7 mice pretreated with KY Jelly became infected. BufferGel provided significant protection compared to $\mathrm{KY}$ jelly $(P<0.01)$ and saline $(P<0.0001)$. 


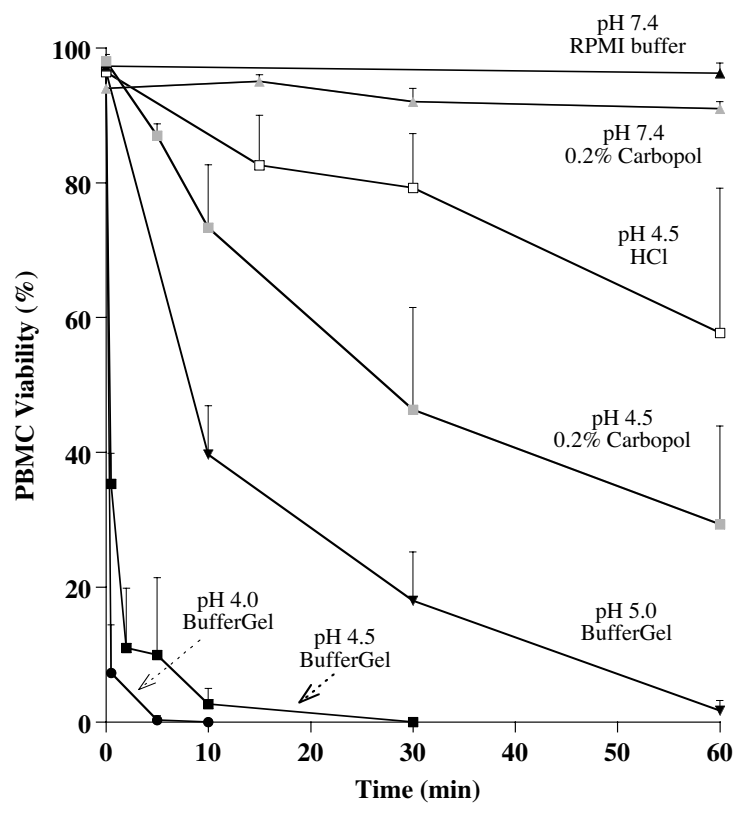

Figure 2

Viability of PBMCs as a function of time and $\mathrm{pH}$. PBMCs in seminal plasma were mixed in various volume ratios $(I: 2, I: I, 2: I)$ with BufferGel to give final $\mathrm{pH}$ values of 4.0, 4.5 and 5.0. Live PBMCs (as detected calcein-AM) and dead PBMCs (as detected by ethidium homodimer) were counted as a function of time and $\mathrm{pH}$. As a comparison, PBMCs in seminal plasma were mixed with a $0.2 \%$ Carbopol (approximately I/20th the amount in BufferGel), and acidified to $\mathrm{pH} 4.5$ with $\mathrm{HCl}$, or maintained at $\mathrm{pH}$ 7.4. Also, PBMCs in seminal plasma without Carbopol were acidified to $\mathrm{pH} 4.5$ with $\mathrm{HCl}$. Each point represents the mean $( \pm \mathrm{SD})$ of three to six experiments. For experiments with BufferGel, results of analysis of variance for the main effects of $\mathrm{pH}$ and time and their interaction were $P<0.00$ I. Scheffe's multiple comparison procedure was used to compare $\mathrm{pH}$ effects. The $\mathrm{pH} 5.0$ curve is significantly different from the $\mathrm{pH} 4.0$ and 4.5 curves $(P<0.001)$. By linear regression, the $\mathrm{pH} 4.5$ BufferGel curve is significantly different from the $\mathrm{pH} 4.5 \mathrm{HCl}$ curve $(\mathrm{P}<$ 0.001 ).

\section{Discussion}

During reproductive years, the $\mathrm{pH}$ of a healthy human vagina is usually $\mathrm{pH} 4-4.5$ [37]. However, Masters and Johnson showed that an ejaculate acts as a potent alkaline buffer, which abolishes vaginal acidity within seconds and keeps the vagina neutralized $(\mathrm{pH} 6-7)$ for several hours after intercourse [38]. During this time acid-sensitive sperm and microbes can reach their targets or enter the upper reproductive tract. Maintaining the normal acidic condition of the vagina during and after intercourse is thus a potential method for preventing conception as well as STDs.

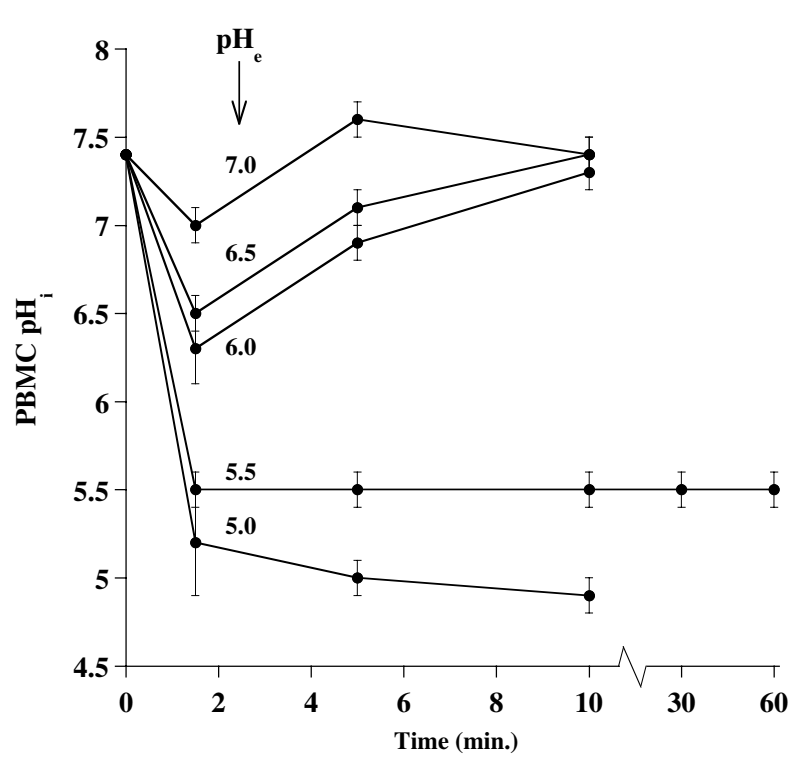

Figure 3

The effect of extracellular $\mathrm{pH}$ on intracellular $\mathrm{pH}$ of PBMCs as a function of time. PBMCs labeled intracellularly with $\mathrm{pH}$ sensitive fluorescent indicators (Oregon Green or carboxyfluorescein), were incubated under varying acidic conditions and monitored over time. Upon acidification, PBMC intracellular $\mathrm{pH}$ undergoes a rapid decrease to or nearly to extracellular $\mathrm{pH}$. At and above $\mathrm{pH}_{\mathrm{e}} 6.0$, PBMCs recover their normal intracellular $\mathrm{pH}(7.3)$ after 5-10 minutes. At $\mathrm{pH}_{\mathrm{e}} 5.5$ and below, PBMCs are unable to recover their intracellular $\mathrm{pH}$. Points are mean $( \pm \mathrm{SD})$ of three experiments.

Here we describe the effect of low pH on the motility and viability of leukocytes that may serve as vectors for sexual transmission of HIV and present data indicating that BufferGel reduces vaginal transmission of cell-associated HIV in the HuPBL-SCID mouse model. We found that monocytes, macrophages and lymphocytes all completely lose progressive motility at a pH slightly below 6.0 (Fig. 1). The results were similar in the presence of a variety of buffering species, including Carbopol, and with a second chemoattractant, platelet activating factor. Our results are consistent with those of Fischer, et al, who showed that lymphocytes lose cytotoxic activity and other immunological functions when the extracellular $\mathrm{pH}$ falls to 5.8 $[39,40]$ and with Hill and Anderson who showed that lymphocyte proliferation is abolished at $\mathrm{pH}<6$ [41].

Acidity dramatically reduced leukocyte viability in this study. When acidified with BufferGel, PBMCs added to seminal plasma were rapidly killed at $\mathrm{pH} 4.0$ and 4.5 , and killed more slowly at pH 5.0 (Fig. 2). Both BufferGel and 
Carbopol alone enhanced acid-killing of PBMCs compared to acidification with $\mathrm{HCl}$ alone.

In the SCID mouse model of vaginal HIV transmission, pretreatment of mice with BufferGel, as compared with saline, significantly reduced the transmission of cell-associated HIV. In addition, BufferGel provided significant protection compared to another gel, KY Jelly. We and others have shown similar protection using this model with other microbicide candidates [13,42-44].

Importantly, despite the cell killing potential of acidity especially in the presence of BufferGel, BufferGel has proven to be non-toxic to cervicovaginal epithelium in vivo in two high-dose tolerance Phase I trials $[19,45]$ and in a highly sensitive acute vaginal toxicity mouse model [46]. We hypothesize that this advantageous differential toxicity (toxic to potentially infectious human leukocytes, but non-toxic to human epithelia in vivo) may be due to a greater ability of the epithelium to maintain the $\mathrm{pH}_{\mathrm{i}}$ of its surface cells because these cells can export protons to underlying vascularized tissue. In contrast, individual cells or pathogens surrounded by an acidic environment within the vaginal lumen must pump out protons against a high gradient over their entire surface area. Thus, although demonstrably cytotoxic to human white blood cells in vitro, and able to prevent cell-associated HIV transmission in the vagina lumen in an animal model, acidic buffering appears to have minimal or no cytotoxicity to the human genital tract epithelium.

Our results demonstrate that mild acidity inactivates the motility and viability of leukocytes that may act as vectors for sexual transmission of HIV $[47,48]$ and reduces transmission of HIV in a mouse model. These results are consistent with other studies that have shown that the natural vaginal acidity may help reduce HIV transmission in women. Women with abundant vaginal lactobacilli have a lower HIV susceptibility compared to women with bacterial vaginosis $[49,50]$, a condition in which vaginal lactobacilli, and therefore, vaginal acidity, are lost. It has been suggested that reduction of cervicovaginal viral load by physiological vaginal acidity may reduce both male to female, and female to male transmission of HIV [51,52]. In a study of HIV infected women, vaginal lavages with a $\mathrm{pH}<4.5$ showed a trend to contain less cultivatable HIV virus than lavages with a $\mathrm{pH} \geq 4.5(\mathrm{P}=0.08)$ when tested with the multinuclear-activation galactosidase indicator (MAGI) assay [52] possibly indicating a reduction in HIV load and a reduction in risk of transmission at lower $\mathrm{pH}$ values. Moreover, another study showed that exposure to acidic cervico-vaginal secretions reduce HIV viability as detected by cocultivation with PBMCs [51].
To gain understanding about how acid $\mathrm{pH}$ mediates the immobilization and killing of leukocytes we measured the $\mathrm{pH}_{\mathrm{i}}$ of PBMCs in acidified medium. Intracellular fluorescent $\mathrm{pH}$ probes have been used to measure the $\mathrm{pH}_{\mathrm{i}}$ of human leukocytes in a number of studies [39,53-57]. Most previous studies have concentrated on leukocyte activation and small changes in $\mathrm{pH}_{\mathrm{i}}(\triangle \mathrm{pH} \sim 0.5)$ and minor reductions in $\mathrm{pH}_{\mathrm{e}}$. One study, exploring leukocyte function near tumors (known to have a low $\mathrm{pH}_{\mathrm{e}}$ ), showed that PBMCs incubated for four hours at low $\mathrm{pH}_{\mathrm{e}}$ were unable to maintain their $\mathrm{pH}_{\mathrm{i}}$ below $\mathrm{pH}_{e} 6.5$ [39]. In our experiments with PBMCs, a significant and continued perturbation of $\mathrm{pH}_{\mathrm{i}}$ was observed at and below a $\mathrm{pH}_{e}$ of 5.5, indicating that PBMCs are unable to defend their $\mathrm{pH}_{\mathrm{i}}$ below this $\mathrm{pH}_{\mathrm{e}}$ (Fig. 3). At $\mathrm{pH}_{\mathrm{e}}$ of 6.0 and above, PBMCs restored their normal $\mathrm{pH}_{\mathrm{i}}$ within 10 minutes. However, even after 60 minutes, PBMCs were unable to restore their normal $\mathrm{pH}_{\mathrm{i}}$ after exposure to a $\mathrm{pH}_{\mathrm{e}}$ of 5.5. Considering that $\mathrm{pH}_{\mathrm{i}}$ exerts profound influence on the apoptosis pathway [58], intracellular enzyme functions, protein stability, and other molecular interactions, we believe the observed prolonged perturbation of $\mathrm{pH}_{\mathrm{i}}$ is the likely cause of the observed loss of motility and viability at low $\mathrm{pH}_{\mathrm{e}}$.

\section{Conclusion}

We found that human leukocytes lose motility and viability at $\mathrm{pH}$ levels typically found in a healthy vagina and that BufferGel reduces transmission of HIV in HuPBLSCID mice. These results support the hypothesis that physiologic vaginal flora and vaginal acidity may reduce female to male HIV transmission via HIV-infected cell vectors. Our results further suggest that by helping to maintain acidity that would otherwise be abolished by semen [38,51], BufferGel, a broad spectrum microbicide/ spermicide $[20,21]$, may enhance the natural protection of vaginal acidity by killing or immobilizing infected cell vectors in semen, and may thus reduce male to female transmission.

\section{Competing interests}

Cone and Moench are developers of BufferGel and Khanna is an employee of ReProtect Inc. All three hold equity in ReProtect, Inc.

\section{Authors' contributions}

SO participated in the design of the study, conducted $\mathrm{pH}_{\mathrm{i}}$ experiments, assisted with statistical analysis, assisted in data analysis and drafted the manuscript. RC conceived of the study, assisted in data analysis, and helped draft the manuscript. KK designed and conducted the HuPBL-SCID mouse experiments, assisted in data analysis, and helped draft the manuscript. EN conducted viability and chemokinesis experiments, and assisted in data analysis. SW participated in the design of the study, conducted chemotaxis and chemokinesis experiments, and participated in 
analysis of the data. OJ conducted $\mathrm{pH}_{\mathrm{i}}$ experiments and assisted in data analysis. RM helped design the HuPBLSCID mouse experiments and assisted in data analysis. TM conceived of and designed the study, supervised experiments, assisted in data analysis, and helped draft the manuscript. All authors read and approved the final manuscript.

\section{Acknowledgements}

The authors thank Leslie A. Meyn, M.S., Magee-Womens Research Institute, Pittsburgh, PA, for statistical analysis and Usman Bacha, Johns Hopkins University, for fluorescent microscopy on individual cells. This work was supported by National Institute of Health Training Grant GM0723 I-23 (SSO, STW), National Institutes of Health Program Project Grant POIAl45967, Gustave Martin Innovative Research Award from the Department of Molecular Microbiology and Immunology, Johns Hopkins Bloomberg School of Public Health (KK) and ReProtect, Inc.

\section{References}

I. Auerbach DM, Darrow WW, Jaffe HW, Curran JW: Cluster of cases of the acquired immune deficiency syndrome. Patients linked by sexual contact. Am J Med 1984, 76:487-492.

2. Chamberland ME, Castro KG, Haverkos HW, Miller BI, Thomas PA, Reiss R, Walker J, Spira TJ, Jaffe HW, Curran JW: Acquired immunodeficiency syndrome in the United States: an analysis of cases outside high-incidence groups. Ann Intern Med 1984, 101:617-623.

3. Pilcher CD, Tien HC, Eron JJJ, Vernazza PL, Leu SY, Stewart PW, Goh LE, Cohen MS: Brief but efficient: acute HIV infection and the sexual transmission of HIV. J Infect Dis 2004, 189: I 785- 1792.

4. Vernazza PL, Gilliam BL, Dyer J, Fiscus SA, Eron JJ, Frank AC, Cohen MS: Quantification of HIV in semen: correlation with antiviral treatment and immune status. AIDS 1997, II:987-993.

5. Quayle AJ, Xu C, Mayer KH, Anderson DJ: T lymphocytes and macrophages, but not motile spermatozoa, are a significant source of human immunodeficiency virus in semen. J Infect $D$ is 1997, I 76:960-968.

6. Tachet A, Dulioust E, Salmon D, De Almeida M, Rivalland S, Finkielsztejn L, Heard I, Jouannet P, Sicard D, Rouzioux C: Detection and quantification of HIV-I in semen: identification of a subpopulation of men at high potential risk of viral sexual transmission. AIDS 1999, 13:823-831.

7. Hart CE, Lennox JL, Pratt-Palmore M, Wright TC, Schinazi RF, EvansStrickfaden T, Bush TJ, Schnell C, Conley LJ, Clancy KA, Ellerbrock TV: Correlation of human immunodeficiency virus type RNA levels in blood and the female genital tract. J Infect Dis 1999, 179:87|-882.

8. Sodora DL, Gettie A, Miller CJ, Marx PA: Vaginal transmission of SIV: assessing infectivity and hormonal influences in macaques inoculated with cell-free and cell-associated viral stocks. AIDS Res Hum Retroviruses 1998, 14 SuppI I:SI 19-23.

9. Girard M, Mahoney J, Wei Q, van der Ryst E, Muchmore E, BarreSinoussi F, Fultz PN: Genital infection of female chimpanzees with human immunodeficiency virus type I. AIDS Res Hum Retroviruses 1998, 14:1357-1367.

10. Burkhard MJ, Obert LA, O'Neil LL, Diehl LJ, Hoover EA: Mucosal transmission of cell-associated and cell-free feline immunodeficiency virus. AIDS Res Hum Retroviruses 1997, 13:347-355.

II. Moench TR, Whaley KJ, Mandrell TD, Bishop BD, Witt CJ, Cone RA: The cat/feline immunodeficiency virus model for transmucosal transmission of AIDS: nonoxynol-9 contraceptive jelly blocks transmission by an infected cell inoculum. AIDS 1993, 7:797-802

12. Di Fabio S, Giannini G, Lapenta C, Spada M, Binelli A, Germinario E, Sestili P, Belardelli F, Proietti E, Vella S: Vaginal transmission of HIV-I in hu-SCID mice: a new model for the evaluation of vaginal microbicides. AIDS 200I, I5:223|-2238.

13. Khanna KV, Whaley KJ, Zeitlin L, Moench TR, Mehrazar K, Cone RA, Liao Z, Hildreth JE, Hoen TE, Shultz L, Markham RB: Vaginal transmission of cell-associated HIV-I in the mouse is blocked by a topical, membrane-modifying agent. I Clin Invest 2002, 109:205-2II.

14. Ibata B, Parr EL, King NJ, Parr MB: Migration of foreign lymphocytes from the mouse vagina into the cervicovaginal mucosa and to the iliac lymph nodes. Biol Reprod 1997, 56:537-543.

15. Zacharopoulos VR, Perotti ME, Phillips DM: A role for cell migration in the sexual transmission of HIV-I? Curr Biol 1997, 7:534-537.

16. Carreno MP, Chomont N, Kazatchkine MD, Irinopoulou T, Krief C, Mohamed AS, Andreoletti L, Matta M, Belec L: Binding of LFA-I (CDIIa) to intercellular adhesion molecule 3 (ICAM-3; CD50) and ICAM-2 (CDIO2) triggers transmigration of human immunodeficiency virus type I-infected monocytes through mucosal epithelial cells. J Virol 2002, 76:32-40.

17. Boskey ER, Cone RA, Whaley KJ, Moench TR: Origins of vaginal acidity: high $D / L$ lactate ratio is consistent with bacteria being the primary source. Hum Reprod 200I, 16:1809-1813.

18. Boskey ER, Telsch KM, Whaley KJ, Moench TR, Cone RA: Acid production by vaginal flora in vitro is consistent with the rate and extent of vaginal acidification. Infect Immun 1999, 67:5170-5175.

19. Mayer K, Peipert J, Fleming T, Fullem A, Moench T, Cu-Uvin S, Bentley M, Chesney M, Rosenberg Z: Safety and tolerability of buffergel, a novel vaginal microbicide, in women in the united states. Clin Infect Dis 200I, 32:476-482.

20. Olmsted SS, Dubin NH, Cone RA, Moench TR: The rate at which human sperm are immobilized and killed by mild acidity. Fertil Steril 2000, 73:687-693.

2I. Zeitlin L, Hoen TE, Achilles SL, Hegarty TA, Jerse AE, Kreider JW, Olmsted SS, Whaley KJ, Cone RA, Moench TR: Tests of Buffergel for contraception and prevention of sexually transmitted diseases in animal models. Sex Transm Dis 2001, 28:417-423.

22. Amaral E, Faundes A, Zaneveld L, Waller D, Garg S: Study of the vaginal tolerance to Acidform, an acid-buffering, bioadhesive gel. Contraception 1999, 60:361-366.

23. Neurath $A R$, Li YY, Mandeville R, Richard L: In vitro activity of a cellulose acetate phthalate topical cream against organisms associated with bacterial vaginosis. J Antimicrob Chemother 2000 , 45:7|3-7|4.

24. Neurath AR, Strick N, Li YY: Water dispersible microbicidal cellulose acetate phthalate film. BMC Infect Dis 2003, 3:27.

25. Neurath AR, Strick N, Li YY, Lin K, Jiang S: Design of a "microbicide" for prevention of sexually transmitted diseases using "inactive" pharmaceutical excipients. Biologicals 1999, 27:II-2I.

26. Meehan A, Chidanyika A, Naidoo S, Didier L, Ramjee G, Chipato T, Dinat N, Blanchard K, team MIRA, Padian N: Prevalence and Risk Factors for HIV Infection in Zimbabwean and South African Women: Preliminary analysis of the MIRA trial screening population.: ; The XV International AIDS Conference; Bangkok, Thailand. ; 2004.

27. Jones BM, Nicholson JK, Holman RC, Hubbard M: Comparison of monocyte separation methods using flow cytometric analysis. J Immunol Methods 1989, I 25:4 I-47.

28. Dougherty G], McBride WH: Monocyte Differentiation in vitro. In Human Monocytes Edited by: Zembala M and Asherson GL. San Diego, Academic Press; 1989:49-58.

29. Huu TP: Chemotaxis of leucocytes: an improved method of direct microscopic observation. Ann Immunol (Paris) 1977, I 28C:763-770.

30. Bright GR, Fisher GW, Rogowska J, Taylor DL: Fluorescence ratio imaging microscopy: temporal and spatial measurements of cytoplasmic pH. J Cell Biol 1987, I04(4):1019-1033.

31. Chaillet JR, Boron WF: Intracellular calibration of a pH-sensitive dye in isolated, perfused salamander proximal tubules. Gen Physiol 1985, 86:765-794.

32. Tanasugarn L, McNeil P, Reynolds GT, Taylor DL: Microspectrofluorometry by digital image processing: measurement of cytoplasmic pH. J Cell Biol I 984, 98(2):7|7-724.

33. Thomas JA, Buchsbaum RN, Zimniak A, Racker E: Intracellular pH measurements in Ehrlich ascites tumor cells utilizing spectroscopic probes generated in situ. Biochemistry 1979, 18:2210-2218.

34. Khanna KV, Whaley KJ, Zeitlin L, Ford DH, Markham RB: Vaginal transmission of HIV-I in Hu-PBL-SCID mice.: ; Poster I 2 I 5 
at Twelth World AIDS Conference; Geneva, Switzerland. ; 1998.

35. Rodbard D, Hutt DM: Statistical analysis of radioimmunoassays and immunoradiometric (labeled antibody) assays: ; Istanbul. Volume I. International Atomic Energy Agency; 1973:165-192.

36. Burghardt RC, Barhoumi R, Doolittle DJ, Philips TD: Application of Cellular Fluorescence Imaging for In Vitro Toxicology Testing. In Principles and Methods of Toxicology 3rd edition. Edited by: Hayes AW. New York, Raven Press; 1994:1231-I 258.

37. Larsen B: Vaginal flora in health and disease. Clin Obstet Gynecol 1993, 36:107-121.

38. Masters WH, Johnson VE: The physiology of the vaginal reproductive function. Western / Surg |961, 69:105-120.

39. Fischer B, Muller B, Fischer KG, Baur N, Kreutz W: Acidic pH inhibits non-MHC-restricted killer cell functions. Clin Immunol 2000, 96:252-263.

40. Fischer B, Muller B, Fisch P, Kreutz W: An acidic microenvironment inhibits antitumoral non-major histocompatibility complex-restricted cytotoxicity: implications for cancer immunotherapy. J Immunother 2000, 23:196-207.

41. Hill JA, Anderson DJ: Human vaginal leukocytes and the effects of vaginal fluid on lymphocyte and macrophage defense functions. Am J Obstet Gynecol 1992, 166:720-726.

42. Di Fabio S, Giannini G, Spada M, Binelli A, Germinario E, Lapenta C, Carlini F, Belardelli F, Vella S: Efficacy of PRO 2000/5 Gel in a huSCID Mouse Model for Vaginal Transmission of Cell-associated HIV: ; Microbicides 2004; London. ; 2004.

43. Di Fabio S, Van Roey J, Giannini G, van den Mooter G, Spada M, Binelli A, Pirillo MF, Germinario E, Belardelli F, de Bethune MP, Vella S: Inhibition of vaginal transmission of HIV-I in hu-SCID mice by the non-nucleoside reverse transcriptase inhibitor TMCI 20 in a gel formulation. Aids 2003, 17:1597-1604.

44. D'Cruz OJ, Samuel P, Uckun FM: PHI-443: a novel noncontraceptive broad-spectrum anti-human immunodeficiency virus microbicide. Biol Reprod 2004, 71:2037-2047.

45. van De Wijgert J, Fullem A, Kelly C, Mehendale S, Rugpao S, Kumwenda N, Chirenje Z, Joshi S, Taha T, Padian N, Bollinger R, Nelson K: Phase I trial of the topical microbicide BufferGel: safety results from four international sites. J Acquir Immune Defic Syndr 200I, 26:2I-27.

46. Achilles SL, Shete PB, Whaley KJ, Moench TR, Cone RA: Microbicide Efficacy and Toxicity Tests in a Mouse Model for Vaginal Transmission of Chlamydia trachomatis. Sex Transm Dis 2002, 29:655-664.

47. Levy JA: The transmission of AIDS: the case of the infected cell. Jama 1988, 259:3037-3038.

48. Anderson DJ, Yunis E]: "Trojan Horse" leukocytes in AIDS. $N$ Engl J Med I 983, 309:984-985.

49. Taha TE, Hoover DR, Dallabetta GA, Kumwenda NI, Mtimavalye LA, Yang LP, Liomba GN, Broadhead RL, Chiphangwi JD, Miotti PG: Bacterial vaginosis and disturbances of vaginal flora: association with increased acquisition of HIV. AIDS 1998, 12:1699-1706.

50. Martin HL, Richardson BA, Nyange PM, Lavreys L, Hillier SL, Chohan $B$, Mandaliya K, Ndinya-Achola JO, Bwayo J, Kreiss J: Vaginal lactobacilli, microbial flora, and risk of human immunodeficiency virus type $I$ and sexually transmitted disease acquisition. J Infect Dis 1999, 180:1863-1868.

5I. Tevi-Benissan C, Belec L, Levy M, Schneider-Fauveau V, Si Mohamed $A$, Hallouin MC, Matta M, Gresenguet $G$ : In vivo semen-associated pH neutralization of cervicovaginal secretions. Clin Diagn Lab Immunol 1997, 4:367-374.

52. Cummins JEJ, Villanueva JM, Evans-Strickfaden T, Sesay SM, Abner SR, Bush TJ, Green TA, Lennox JL, Wright T, Folks TM, Hart CE, Dezzutti CS: Detection of infectious human immunodeficiency virus type $I$ in female genital secretions by a short-term culture method. J Clin Microbiol 2003, 4I:408I-4088.

53. Grinstein S, Cohen S, Lederman HM, Gelfand EW: The intracellular $\mathrm{pH}$ of quiescent and proliferating human and rat thymic lymphocytes. J Cell Physiol 1984, I 2 I:87-95.

54. Grinstein S, Cohen S, Rothstein A: Cytoplasmic pH regulation in thymic lymphocytes by an amiloride-sensitive $\mathrm{Na}+/ \mathrm{H}+$ antiport. J Gen Physiol 1984, 83:34I-369.

55. Swallow CJ, Grinstein S, Rotstein OD: Cytoplasmic pH regulation in macrophages by an ATP-dependent and N,N'-dicyclohexylcarbodiimide-sensitive mechanism. Possible involvement of a plasma membrane proton pump. J Biol Chem 1988 263:19558-19563.

56. Swallow CJ, Grinstein S, Rotstein OD: Regulation of cytoplasmic $\mathrm{pH}$ in resident and activated peritoneal macrophages. Biochim Biophys Acta 1990, 1022:203-210.

57. Swallow C], Grinstein S, Rotstein OD: Regulation and Functional Significance of Cytoplasmic pH in Phagocytic Leukocytes. In Mechanisms of leukocyte activation Edited by: Grinstein S and Rotstein OD. San Diego, Academic Press; 1990:227-247.

58. Meisenholder GW, Martin SJ, Green DR, Nordberg J, Babior BM, Gottlieb RA: Events in apoptosis. Acidification is downstream of protease activation and BCL-2 protection. J Biol Chem 1996, 27I:16260-16262.

\section{Pre-publication history}

The pre-publication history for this paper can be accessed here:

http://www.biomedcentral.com/1471-2334/5/79/prepub
Publish with Biomed Central and every scientist can read your work free of charge

"BioMed Central will be the most significant development for disseminating the results of biomedical research in our lifetime. "

Sir Paul Nurse, Cancer Research UK

Your research papers will be:

- available free of charge to the entire biomedical community

- peer reviewed and published immediately upon acceptance

- cited in PubMed and archived on PubMed Central

- yours - you keep the copyright

Submit your manuscript here:

http://www.biomedcentral.com/info/publishing_adv.asp
BioMedcentral 